\title{
An Aspect of Palyno Stratigraphy of "XM" Field Located in Semliki Basin South Western Uganda
}

\author{
Stephen Mutebi*, Bertram M Ozumba and Olubunmi C Adeigbe \\ Department of Geology, University of Ibadan, Nigeria
}

\begin{abstract}
"XM" field, a clastic sedimentary domain within the Albertine Graben, southwestern Uganda, was studied using palynological data, complemented with wire-line well logs, to determine the stratigraphy, age, and depositional setting. Field wide correlation was attempted using additional geological and stratigraphical data from the larger Albertine Graben.

The study involved the use of geological computing tools such as Petrel and Strata Bug softwares which allowed for the graphic plots of palynoflora, identification of marker species, species abundances, species first and last occurrences and the geological correlation of the two wells. The palynological marker species identified include; Podocarpus spp., Tournefortia spp., Praedapollis flexibilis, Peregrinipollis nigericus, Gramineae spp., Laevigatosporites spp. and Verrucatosporites usmensis. This association of species indicates Early Pliocene to Holocene age. These species were further used in delineating the Early Pliocene age of well T2 into TZ1a and TZ1b. The TZ1a subzone is marked by index species of Laevigatosporites spp., the quantitative top occurrence of Sapotaceae spp. and Verrucatosporites usmensis. TZ1b is marked by the presence of index species of Laevigatosporites spp. and top occurrence of Sapotaceae spp.

Further, the study revealed five informal palynological biozonation of the well T3 into; TZI, TZII, TZIII, TZIV and TZV all ranging in age from Early Pliocene to Holocene and defined based on top occurrences, downhole increases and decreases of some of the stratigraphical important species recorded in the well as follows: TZI is marked by the top occurrence of index specie Gramineae spp. TZII by the presence of index specie of Peregrinipollis nigericus and top occurrence of Praedapollis flexibilis. TZIII is defined by top occurrence of Tournefortia spp. and the downhole decrease in Podocarpus spp. TZIV is defined by the top downhole increase in Podocarpus spp. and TZV by the base downhole decrease in Podocarpus spp.

In arriving at these interpretations, data and publications from other basins such as the Niger Delta in West Africa and the Muglad and Burundi Basins in Central and East Africa were used as analogues. The age of the drilled wells ranged from Early Pliocene to Holocene while the paleo environment of deposition was determined to be mostly continental ranging from fluvial to lacustrine settings.
\end{abstract}

Keywords: Palyno stratigraphy; Niger delta; Semliki basin

\section{INTRODUCTION}

Studies in the Semliki Basin of southwestern Uganda have not yielded definitive age control for the basin. Age determinations from sedimentological cores are hardly in agreement with those from outcrop samples. In view of the critical role played by biostratigraphy in sequence analysis, this study intends to establish both the relative and the absolute ages of the succession traversed by wells in the basin. The best sequence stratigraphic models of the sedimentary fill of basins are built using a combination of seismic data, well logs and cores and outcrop information in conjunction with biostratigraphy data [1].

\section{Study area}

The basin under study is located in Albertine Graben, south western Uganda (Figure 1). Uganda is a landlocked country located astride the Equator in East Africa. It is bordered to the east by Kenya, to the north by South Sudan, to the west by the Democratic Republic of the Congo, to the southwest by Rwanda, and to the south by Tanzania. It is in the heart of the Great Lakes region, and

Correspondence to: Stephen Mutebi, Department of Geology, University of Ibadan, Nigeria, Tel: +256703717850; E-mail: mutebisteve@gmail.com

Received: January 22, 2019, Accepted: February 11, 2019, Published: February 18, 2019

Citation: Mutebi S, Ozumba BM, Adeigbe OC (2018) An Aspect of Palyno Stratigraphy of "XM" Field Located in Semliki Basin South Western Uganda. J Pet Environ Biotechnol 9: 388. doi: 10.35248/2157-7463.19.10.388

Copyright: (C) 2019 Mutebi S, et al. This is an open-access article distributed under the terms of the Creative Commons Attribution License, which permits unrestricted use, distribution, and reproduction in any medium, provided the original author and source are credited. 
the southern part of the country includes a substantial portion of Lake Victoria, which is also shared by Kenya and Tanzania. Uganda has a population in 2017 of about 42.86 million according to the World Bank.

The Semliki basin covers an area of approximately $740 \mathrm{~km}^{2}$ in the Ugandan portion of the Albertine Graben. It comprises the Semliki flats and the adjacent Toro Plain, southwest of Lake Albert. It is bordered to the south east by a steep fault escarpment rising almost $1,000 \mathrm{~m}$ to the northernmost spur of the Rwenzori Mountains (Figure 2). The area is distinct from the surrounding areas of Uganda and the Democratic Republic of Congo (DRC) because of its low elevation of about $650 \mathrm{~m}$ above mean sea level compared with about 1,100 to $1,500 \mathrm{~m}$ for the adjoining rift shoulders to the east and 1,500 to $1,800-\mathrm{m}$ to the west. Up to 700 m of Neogene sediments are thought to be exposed in tributary valleys to the Semliki River in the area, although estimates have varied between Wayland and Pickford et al., who suggested around $600 \mathrm{~m}$, and Bishop with "at least" 1,300 m [2-4].

Semliki River originates from lake Edward found in Kasese District in Western Uganda. Lake Edward is found in Queen Elizabeth National Park on the border of Uganda and the Democratic Republic of Congo. The river flows northwards and empties into Lake Albert located in the Hoima District in Western Uganda at $1.2225^{\circ} \mathrm{N} 30.5038889^{\circ} \mathrm{E}$. The river travels $230 \mathrm{~km}$ along the Rwenzori range and the border between Uganda and Democratic Republic of Congo from Lake Edward to Lake Albert. Semliki River forms the boundary between Uganda and the Democratic Republic of Congo. In Lake Albert, the Nile is joined by river
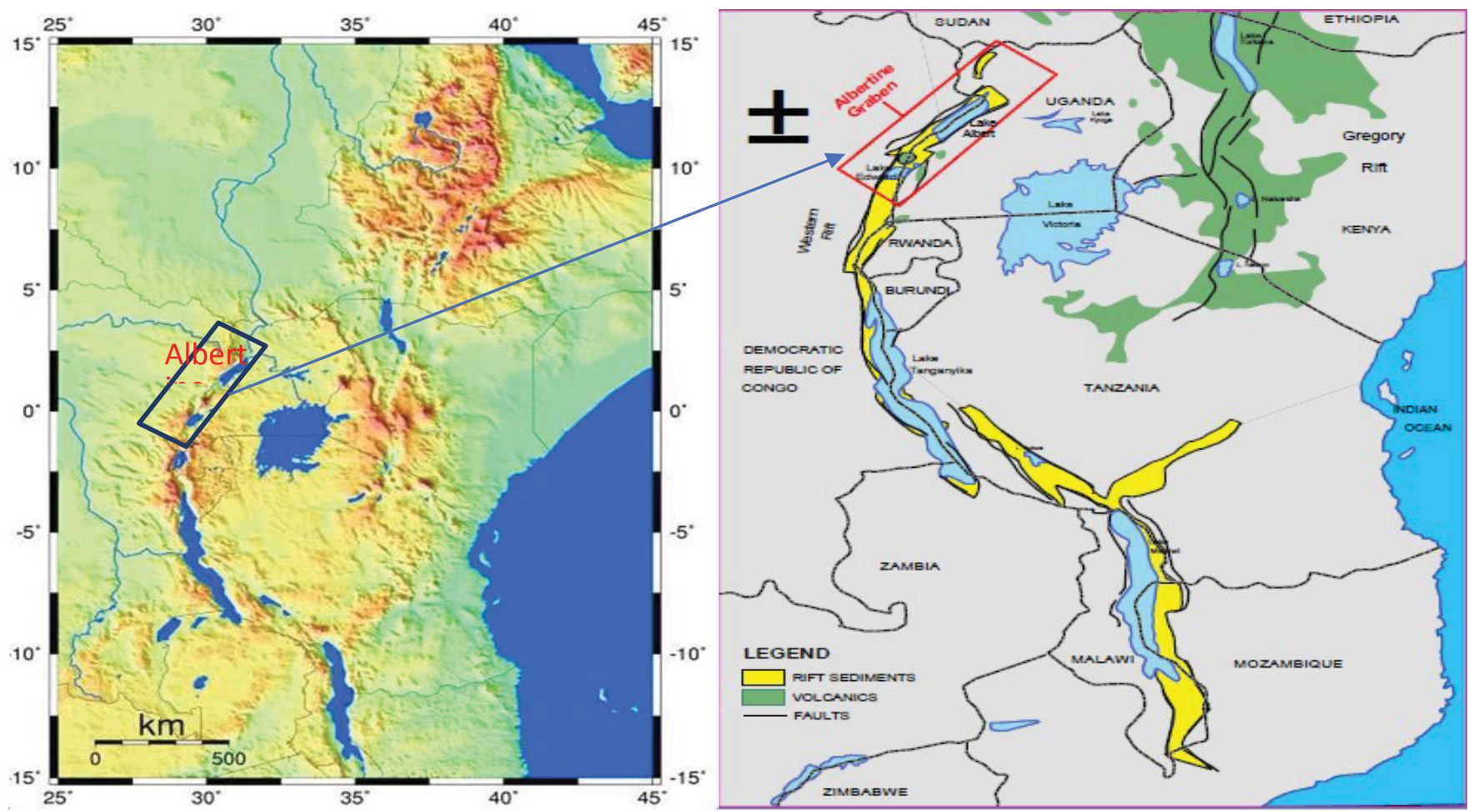

Figure 1: Location map of the Albertine Graben [6].

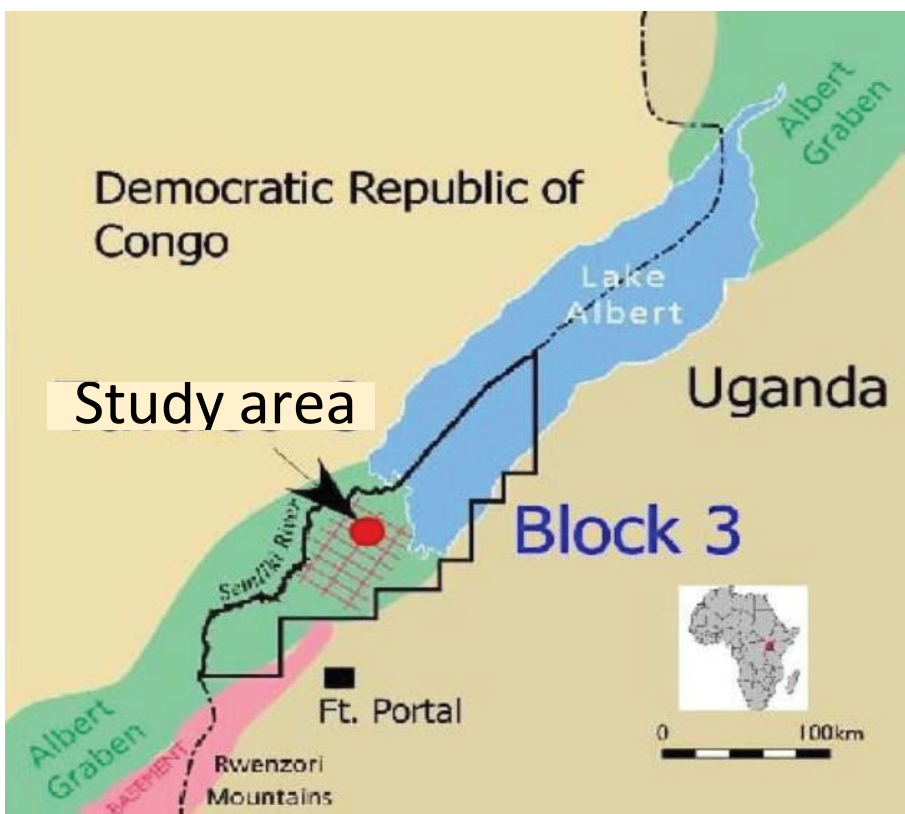

Figure 2: Location map of the study area. 
Semliki which drains Lakes George and Edward found in the rift valley and the high rainfall area of the Rwenzori Mountains [5].

In the subsurface, almost 3,000 m thick sequence has been penetrated by the exploration wells without reaching the basement. Geophysical surveys suggest a $6 \mathrm{~km}$ sediment thickness below southern Lake Albert immediately to the north of the field under study. The successions comprise of seven formations, namely; Kisengi, Kasande, Kakara, Oluka, Nyaburongo, Nyakabingo and Nyabusosi Formations [6].

\section{Stratigraphy}

The general stratigraphic sequence of Lake Albert is divided into two mega-sequences: Pre-rift and Syn-rift. The pre-rift megasequence is composed of Pre-Cambrian basement rocks exposed on the rift flanks. This sequence consists of high-grade metasedimentary rocks, gneisses, granite gneisses and quartzites. These rocks have no source potential but could prove to act as reservoirs if fractured and sealed. The syn-rift mega-sequence uncomfortably overlies the pre-rift rocks. Most of the syn-rift succession is of Cenozoic age, possibly ranging from the Paleogene/Early Miocene to Recent. However, the lowest part of the sedimentary section in Lake Albert is possibly Jurassic, though this is based only on lithological similarities through correlation of a bituminous black shale discovered by the Butaiba Waki-1 well in Uganda and the Stanleyville shales found elsewhere in the Congo. Although this formation is found in Lake Albert, it may or may not be found in either the northern or southern part of Block III under Semliki basin.

The Cenozoic sequence was penetrated by several wells and is also exposed on the flanks of the rift. Sequences found in the Turaco wells (10 km from Block III) and those further away in wells drilled on the Ugandan side of Lake Albert generally correlate to each other. The sequence is divided into two main formations namely the Kisegi and Kaiso Formations which are separated by an unconformity.

\section{Geology}

Uganda is underlain by some of the world's oldest rocks, dating up to 3 billion years. A large part of these rocks were modified by deepseated mountain-building processes, which extended throughout the Precambrian and up to the beginning of Cambrian time approximately 500 million years ago. At this time, the mountain building movements apparently ceased and the area became a continental environment except for the marine incursions as evidenced by the fossiliferous series extending from the Cambrian to Recent times. Tiny pockets of Karoo shales exist in south-eastern Uganda indicating that the Permo-Triassic Karoo deposition of southern Africa must have extended as far as Uganda.

Rifting started affecting the area during the Tertiary resulting in the commencement of active geological deposition. Since this time, rift movements became very important in the western rift valley as it formed and filled with sediments. The latest stages in the formation of the rift gave rise to renewed volcanic activity in the southwestern parts of the country and a general sag in the centre of the country. The latter led to the formation of the Lakes Kyoga and Victoria drowned sag basins. Magmatism in the area began approximately $11 \mathrm{Ma}$ and this might be consistent with the faulting activity which weakened northwards.
The Semliki Basin lies within EA3 block in the Albertine Graben, Uganda. The Uganda portion of the covers the southern part of Lake Albert on the landward area to the south of the lake. This includes the eastern part of flood plain of the Semliki River and Lake Albert, known as the Semliki flats, as well as the adjacent Toro plain, a slightly more elevated scarp land to the east of the flood plain. The topography of the study Basin is distinct from the rest of western Uganda largely because of its lower elevation of about $650 \mathrm{~m}$ above mean sea level compared with about $1650 \mathrm{~m}$ for the adjoining rift shoulders [7].

The seismic data shows that most of the East African rift grabens are asymmetrical. These grabens are bordered by major normal fault on one side and a faulted flexure on the other side. The main grabens resulted from a long structural evolution which began during the Miocene or late oligocene times and continued through the present. The main grabens are divided into smaller basins by northwest - southeast striking transfer fault zones.

\section{Tectonic setting of the Albertine Graben}

The Albertine Graben can be divided into three structural domains: The Southern Domain, the Central Domain and the Northern Domain (Figure 3). The general structural trends in the Central domain are NE-SW and almost N-S trends in the Northern and Southern Domains probably following the pre-existing basement fabric [8].

Compared to the eastern arm of the East African Rift system, the Albertine Graben contains much less volcanic and intrusive and comprises thick sequences of Gneiss and schist. The Semliki Basin is separated from the Lake Albert Basin to the north by an accommodation zone (Figure 4). The trend of the rift changes from NE-SW in the Lake Albert Basin to NNE-SSW in the Semliki Basin. The Semliki Basin terminates against the Rwenzori Mountains to the southeast.

\section{METHODOLOGY}

The data set for this study are wireline well logs and biostratigraphy data. Wireline log data from the wells used include gamma ray and sonic logs. The interpretation was carried out using Strata Bug, and a palynostratigraphic chart was generated.

Palyno facies analysis involved extracting data samples of flora from a report and an independent analysis. Palynological preparations were made from the ditch cuttings samples at approximately $20 \mathrm{~m}$. Intervals, in T-3, 136 samples between depth intervals $17-2841 \mathrm{~m}$ were analyzed. T-2 had 12 samples analyzed between 2750-2963.7 $\mathrm{m}$ depth. It should be noted, however, that wireline logs from the upper part of the T-1 section were used within the interpretation of T-3. T-3 lies $105 \mathrm{~m}$ to the west-north-west of T-1 (and its re-entry $\mathrm{T}-2)$ (Figure 5).

The analysis was carried out using strata bug software, which enables the plotting of palyno-flora by depth, matched with well logs (gamma ray and sonic). Marker fossils were used in distinguishing different palynological zones and ages identified and compared with other basins in West Africa (e.g., Niger Delta) and in Sudan. The ages mapped are based on the Gradstein et al. 2012 age model [9] (Figure 6).

\section{RESULTS}

A plot of diversity and abundance in "XM" Field (Figures 7 and 8; Tables 1 and 2). 


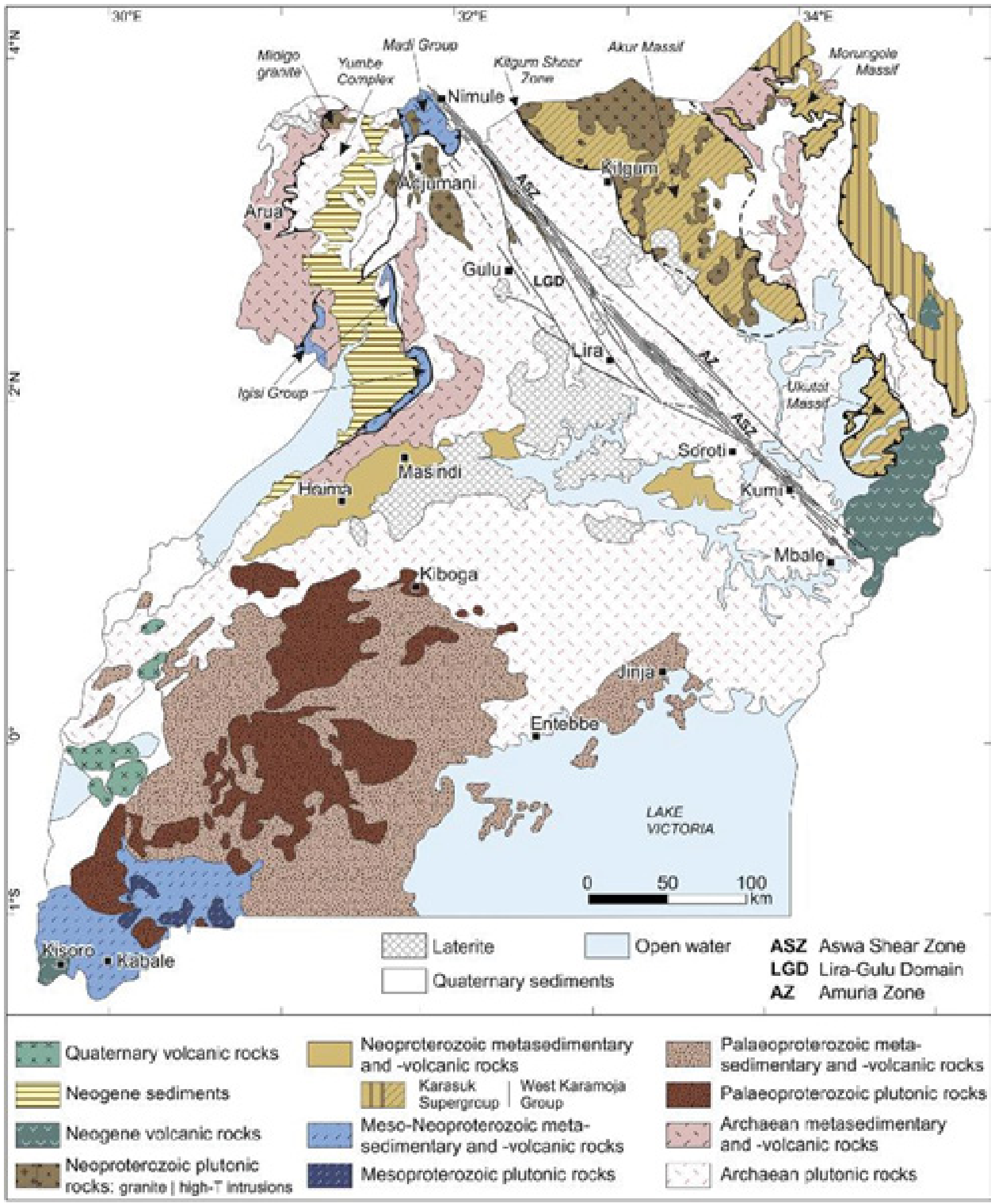

Figure 3: Geological map of Uganda (Modified after GTK Consortium, 2014).

\section{DISCUSSION}

\section{Palynostratigraphy}

In the basin under study, the palynofloras are generally characterized by well-preserved miospores, i.e., most of the samples yielded rich and diverse palynomorphs.

Palynostratigraphic summary of the T-2 well. Interpretations were carried out on T-2 well palynological data set. The well recorded fairly abundant pollen, abundant fresh water algae, fungal spores and hyphae.

The down-hole decreases, quantitative tops and rare occurrence of few stratigraphically significant species allowed for the Palynobiozonation of the well into the TZIa and TZIb zones. These zones have been related to the pantropical Echitricolporites spinosus zone of Germeraad et al. and dated Early Pliocene [10]. The zones are briefly discussed below. 

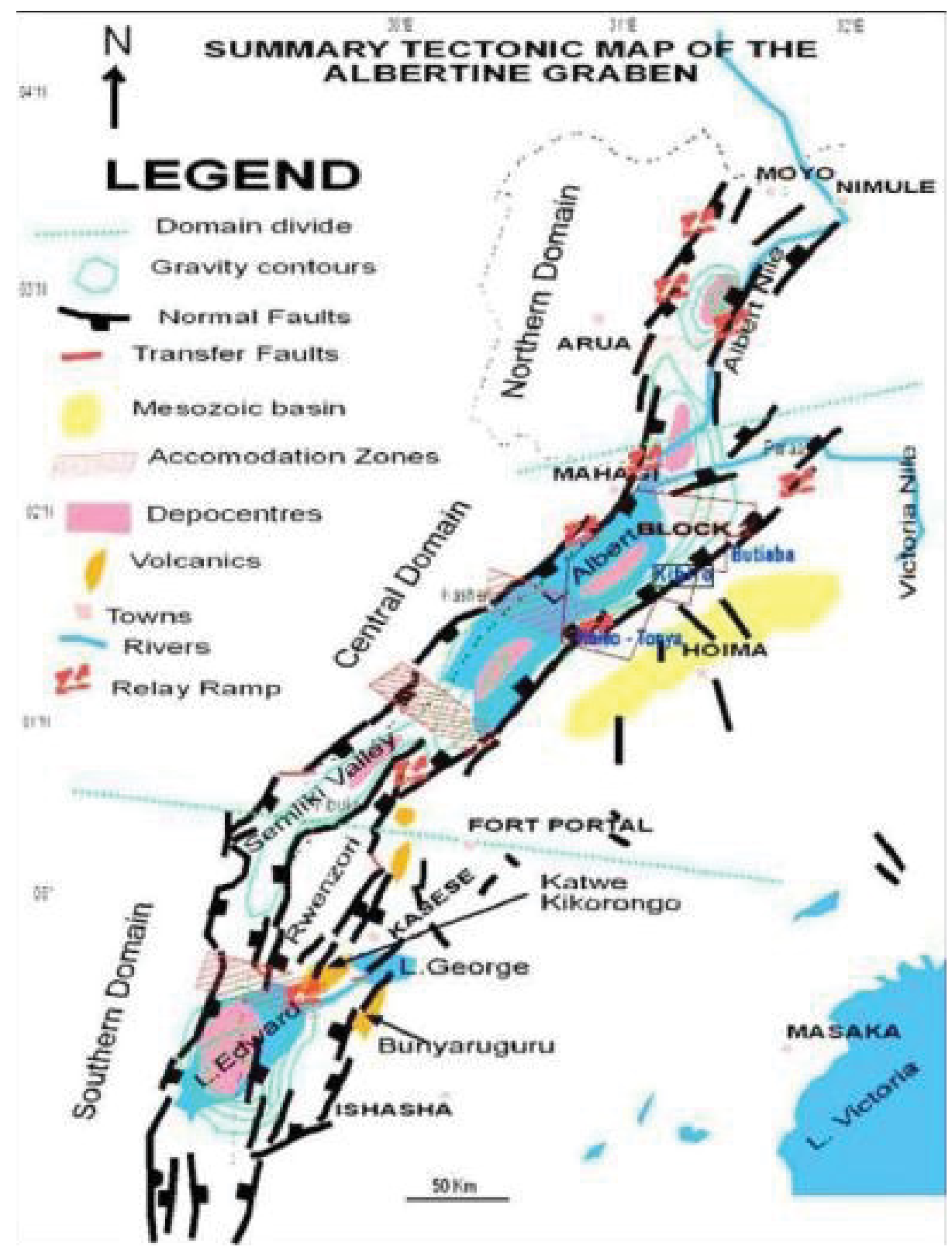

Figure 4: Structural setting of the Albertine Graben [8].

100.0
90.0
80.0
70.0
60.0
50.0
40.0
30.0
20.0
10.0
0.0
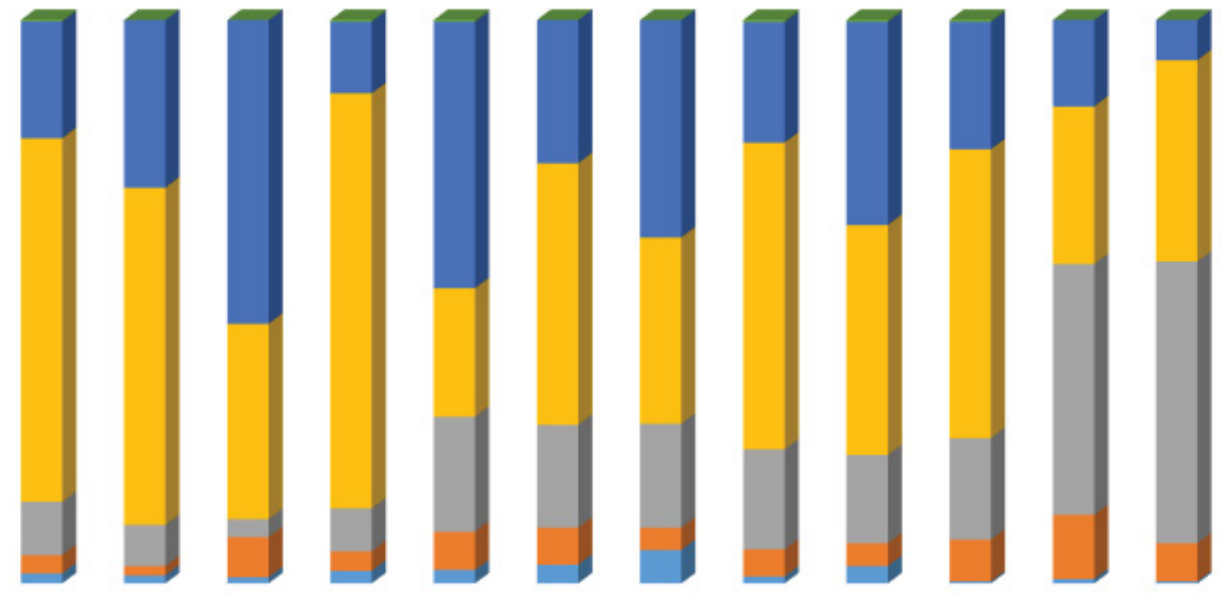

27502775

27902810283528552875

28902915293029502963

- Tropical Forest

freshwater algae घavannah \& Bushland $\quad$ Ferns

- Fungal spores \& hyphae — Insect/Worm jaw

Figure 5: Palynofacies data of T-2 well. 


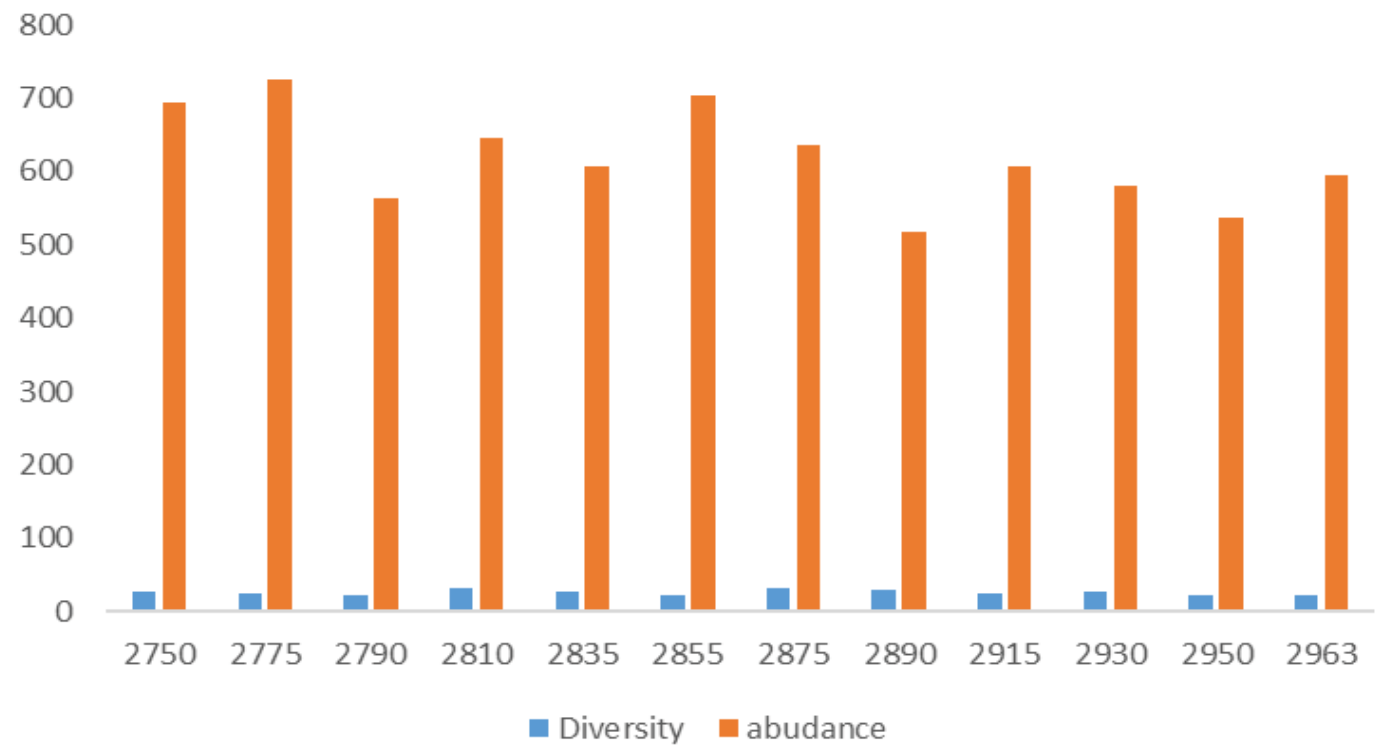

Figure 6: Diversity and abundance at different depths in well T-2.

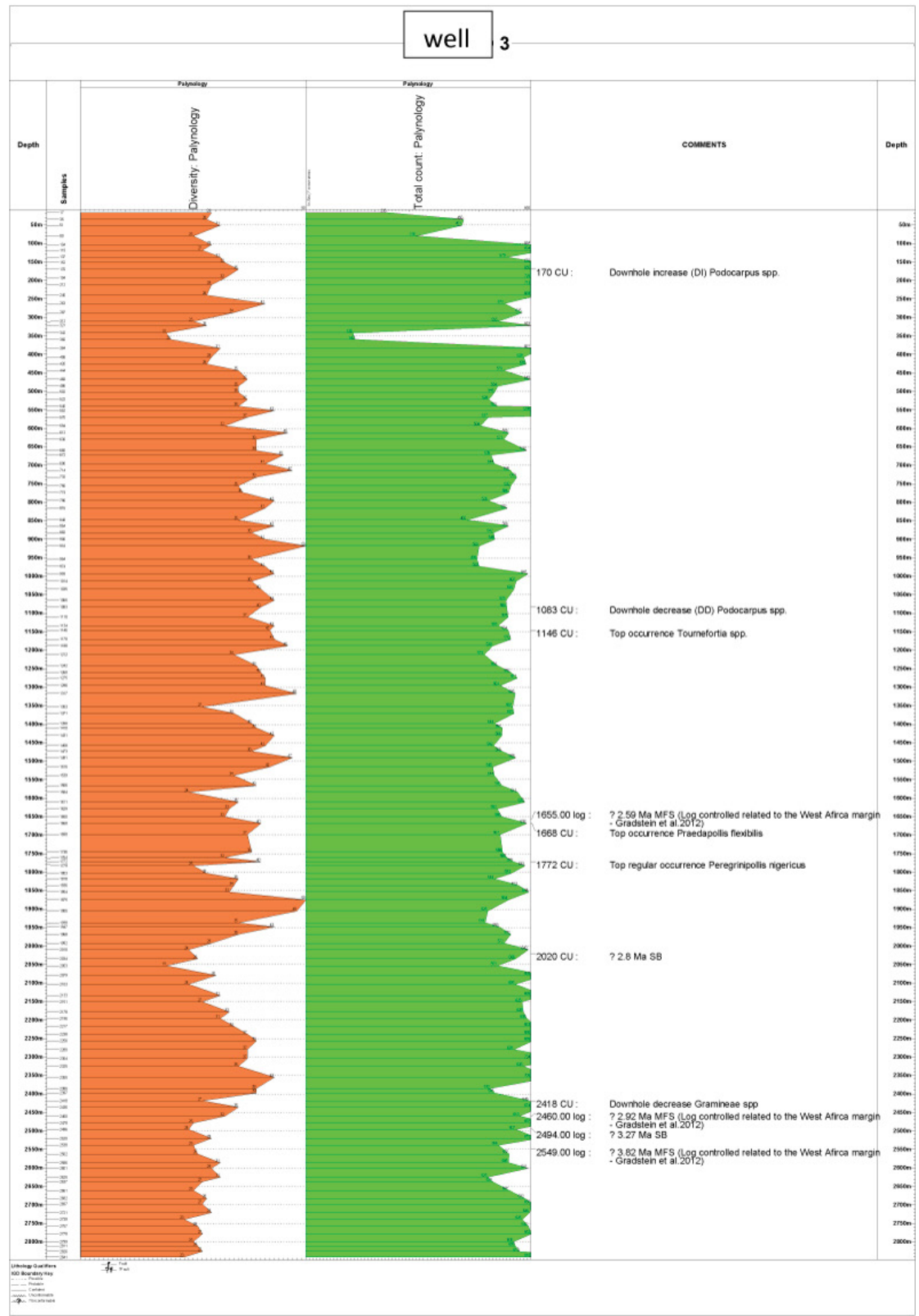

Figure 7: Diversity and abundance of palynomophs in well T3. 


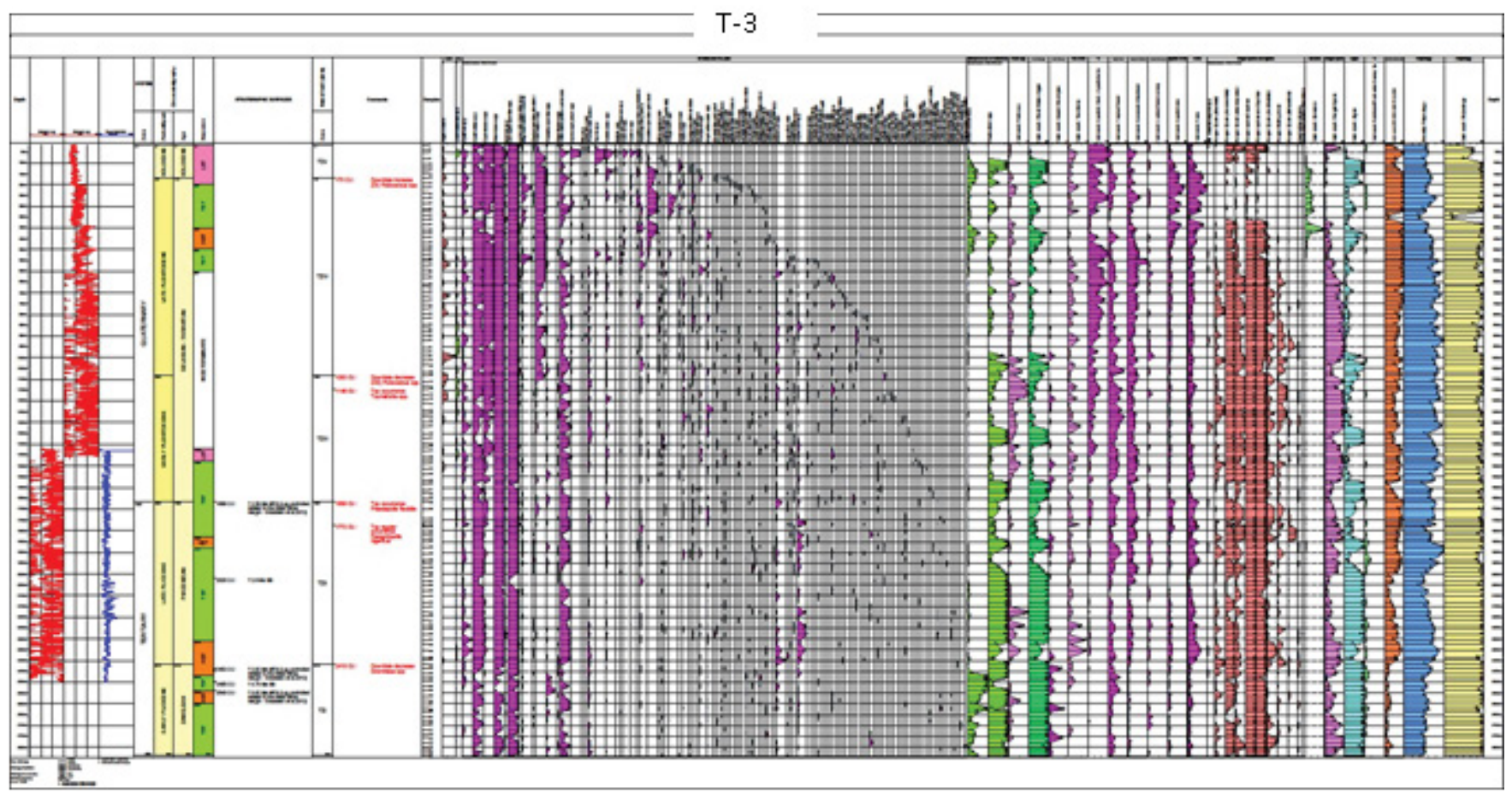

Figure 8: a and b) Palyno stratigraphic interpretation of T-well in Study area.

\begin{tabular}{|c|c|c|c|c|c|c|}
\hline Depth (meters) & System/Period & Series/Epoch & Stage/Age & Germeraad et al. & This Study & Bio-markers events \\
\hline 2750 & \multirow{5}{*}{ Tertiary } & \multirow{5}{*}{ Early pleistocene } & \multirow{5}{*}{ Zanclean } & \multirow{5}{*}{$\begin{array}{l}\text { Echitricolporites } \\
\text { spinosus zone }\end{array}$} & & \multirow{3}{*}{$\begin{array}{l}\text { Downhole increase in Botryococcus braunii / + } \\
\text { downhole decrease occurrece of Gramineae spp. }\end{array}$} \\
\hline $2750-2775$ & & & & & TZIb & \\
\hline $2775-2855$ & & & & & & \\
\hline $2855-2890$ & & & & & \multirow[t]{2}{*}{ TZIa } & $\begin{array}{l}\text { Increased occurrence of Laevigatosporites spp. / } \\
\text { quantitative top occurrence of Sapotaceae }\end{array}$ \\
\hline $2890-2963$ & & & & & & Rare occurrence of Pachydernites diederixi \\
\hline
\end{tabular}

Table 1: Palynostratigraphic zones identified in 1-2 wen (2750-2963 m).

\begin{tabular}{|c|c|c|c|c|c|c|}
\hline Depth (meters) & System/Period & Series/Epoch & Stage/Age & Germeraad et al. & This Study & Bio-markers events \\
\hline 17 & \multirow{5}{*}{ Quaternary } & Holocene & Holocene & \multirow{8}{*}{$\begin{array}{l}\text { Echitricolporites spinosus } \\
\text { zone }\end{array}$} & TZV & \multirow[b]{2}{*}{ Downhole INcrease in Podocarpus spp. } \\
\hline $17-170$ & & $\begin{array}{c}\text { Late } \\
\text { pleistocene }\end{array}$ & \multirow{4}{*}{ Gelasian-Tarantian } & & TZIV & \\
\hline $170-1083$ & & \multirow{3}{*}{$\begin{array}{c}\text { Early } \\
\text { pleistocene }\end{array}$} & & & \multirow{3}{*}{ TZIII } & Downhole decrease in Podocarpus spp. \\
\hline $1083-1146$ & & & & & & Top occurrence of Tournefortia spp. \\
\hline $1146-1668$ & & & & & & Top occurrence of Praedapollis flexibilis \\
\hline $1668-1772$ & \multirow{3}{*}{ Tertiary } & \multirow{2}{*}{$\begin{array}{c}\text { Late } \\
\text { pleistocene }\end{array}$} & \multirow[t]{2}{*}{ Piacenzian } & & \multirow[t]{2}{*}{ TZII } & $\begin{array}{c}\text { Top regular occurrence of Peregrinipollis } \\
\text { nigericus }\end{array}$ \\
\hline $1772-2496$ & & & & & & Downhole decrease of gramineae spp. \\
\hline $2496-2841$ & & $\begin{array}{c}\text { Early } \\
\text { pleistocene }\end{array}$ & Zanclean & & TZI & \\
\hline
\end{tabular}

Table 2: Palynostratigraphic zones identified in T-3 well (17-2841 m).

Zone TZIa: Presented top depth: $2855 \mathrm{~m}$. Base depth: $2963 \mathrm{~m}$. Suggested age: early Pliocene (Zanclean).

Discussion: The base of this zone coincides with the last samples analyzed while the top is defined by the increased occurrence of Laevigatosporites spp. and the quantitative top occurrence of Sapotaceae spp. at $2855 \mathrm{~m}$. The abundant occurrence of pteridophytic spores such as Laevigatosporites spp. and Verrucatosporites usmensis with abundant freshwater algae generally depicts a fluvial depositional environment.

Final Zone TZIb: Top depth: $2750 \mathrm{~m}$. Base depth: $2855 \mathrm{~m}$. Age: Early Pliocene (Zanclean).
Discussion: The base of this zone is defined by the increased occurrence of Laevigatosporites spp. as well as the quantitative top occurrence of Sapotaceae spp. marked at $2855 \mathrm{~m}$. The top coincides with the first sample analyzed. The downhole increase in Verrucatosporites usmensis, Cyathidites $\mathrm{sp}$. and the relative common to downhole decrease in gramineae at $2775 \mathrm{~m}$ are other palynofloral events recorded within this zone. The presence of Verrucatosporites usmensis in Muglad Basin and Burundi gave rise to the earlier dating of Pliocene-Miocene [11]. However, newer of Pliocene in Congo and West Africa has put the zone suggested to be early Pliocene as identified in T-2 [12]. This also agrees with Lukaye's dating of 
mid-Pliocene-Pleistocene [13]. Adeonipekun classifies this zone as in the lower part of Zone P7 and is characterized by abundance of cf. Cleistopholispatens pollen and Sapotaceae pollen; consistent or common Retibrevitricolporites obodoensis/protrudens, Laevigatosporites spp. Zonocostites ramonae, Monoporites annulatus, Echiperiporitesica cinoides, Retitricolporites irregularis and Pachydermites diederixi dated early Pliocene [14].

Palynostratigraphy summary of the T-3 well. The well penetrates early Pliocene to Holocene age. This compares with other basins in West Africa (Niger Delta) and in Sudan. The ages mapped are based on Gradstein et al. age model [9].

Palynostratigraphic interpretations were carried out on T-3 well palynological analysis result. The well recorded fairly abundant pollen, spores which are quantitatively dominated by ferns such as Laevigatosporites spp. and Verrucatosporites usmensis, rainforest species such as Echitricolporites spinosus, mountain species Podocarpus spp. and grass pollen Gramineae. Abundant fresh water algae such as Botryococcus spp., Pediastrum spp. and fungal spores and hyphae are also identified in the well.

Based on top occurrences, downhole increases and decreases of the few stratigraphic important species recorded in the well, five informal palynobiozonation namely: TZI, TZII, TZIII, TZIV and TZV were defined ranging from early Pliocene to Holocene. These were correlated to the Pan Tropical Echitricolporites spinosus palynological zone of Germeraad et al. [10]. Details of the zones are briefly discussed below.

Zone TZI: Top depth: 2496 m. Base depth: 2841 m. Age: Early Pliocene (Zanclean).

Discussion: The top of this zone is marked by the downhole decrease in savannah pollen Gramineae spp. Rainforest species show fairly abundant occurrence while the savannah records show reduction. Suggested age is early Pliocene (Zanclean). In the Niger Delta Gramineae spp. is dated as Pliocene- Miocene, while in Muglad Basin Sudan, it is dated Pliocene (Quaternary; Post-Adok Formation) [15].

Zone TZII: Top depth: 1668 m. Base depth: 2496 m. Suggested age: Late Pliocene.

Discussion: The top is defined by the top occurrence of Praedapollis flexibilis while the base is marked by the downhole decrease in Gramineae species. The top regular occurrence of Peregrinipollis nigericus is marked at $1772 \mathrm{~m}$. Suggested age is Late Pliocene (Piacenzian), in the Niger Delta, it is dated Pliocene. The zone marks the boundary between Early/Late Pliocene boundary [1], and dated Pliocene (Adol-2a) in Muglad Basin, South Sudan [13,16-18].

Zone TZIII: Top depth: 1083 m. Base depth: 1668 m. Age: Early Pleistocene.

Discussion: The top of this zone is marked by the downhole decrease in Podocarpus spp. at $1083 \mathrm{~m}$, while the top occurrence of Praedapollis flexibilis at $1668 \mathrm{~m}$ defines the base. Also, the top occurrence of Tournefortia spp. at $1146 \mathrm{~m}$ corroborates this age of deposition [19]. In the Niger Delta Praedapollis flexibilis zone is dated Pliocene - Pleistocene ZONE FF5, Echitriletes pliocenicusPodocarpus milanjianus zone (late Pliocene-earliest pleistocene) [14].

Zone TZIV: Top depth: 170 m. Base depth: 1083 m. Age: Late Pleistocene.
Discussion: The top downhole increase in Podocarpus spp. at 170 $\mathrm{m}$ while the downhole decrease of this mountain species recorded $1083 \mathrm{~m}$ defines the base of this zone. suggested age, late pleistocene (the top downhole increase in Podocarpus spp.) dated Pleistocene in Burundi, in the Niger Delta the abundance Podocarpus spp. is correlated to zoned P900 and dated Pleistocene [14,20].

Zone TZV: Top depth: $17 \mathrm{~m}$. Base depth: $170 \mathrm{~m}$. Suggested Age: Holocene.

Discussion: This is the youngest zone in the well. The top of this zone is the first sample analyzed. The base is marked by the downhole decrease in Podocarpus spp. In summary, the analysis revealed five informal Palyno-zones with ages ranging from early Pliocene to recent (5.33 Ma-0.0082 Ma) [9].

\section{CONCLUSION AND RECOMMENDATIONS}

The palynologic analysis reveals that the drilled wells penetrated early Pliocene to holocene sediments. This agrees with Lukaye et al. and RPS report, although different authors have mapped this basin and reported middle Miocene to Recent age range [6].

Five informal biozones were identified compared to four zones identified by Lukaye [13]. However, it should be noted that the drilled wells did not reach the Basement since most of age dating was based on outcrops that sit non-conformably on the Basement, thus leaving an age gap between the dated outcrops and the subsurface core analysis. The paleo-depositional environment ranges from fluvial to lacustrine [21].

More wells should be drilled in Semliki Basin to enable more accurate analysis. More biostratigraphy studies should be done to harmonize the exact age of the subsurface formations with that of the outcrops possibly using nanno-studies. Other dating techniques such as radiometric and magnetostratigraphy, need to be applied to confirm the absolute ages within the basin.

\section{ACKNOWLEDGEMENTS}

Special thanks go to the Government of Uganda and Ministry of Energy \& Mineral Development, for availing an opportunity to use the data set of Semliki Basin for the study and the Pan African University (PAULESI), University of Ibadan, Nigeria, for the support.

\section{REFERENCES}

1. Obaje SO. Sequence Stratigraphic Interpretation of Kafe1 Field, Offshore Western Niger Delta, Nigeria. Int J Eng Sci Invent.2013;2:20-30.

2. Wayland EJ. Petroleum in Uganda. Memoir I:Geological Survey of Uganda.1925;4:1-33.

3. Pickford M, Senut B, Hadoto D. Geology and palaeobiology of the Albertine Rift Valley, Uganda Zaire. CIFEG Publication Occasionelle,1994:p:2.

4. Bishop WW. Pleistocene stratigraphy in Uganda. Mem Geol Surv Uganda.1969;10:1-128.

5. Nsubuga FN, Namutebi EN, Nsubuga-Ssenfuma M Water resources of Uganda:An assessment and review. J Water Res Protect. 2014;6:12971315.

6. Lukaye J, Worsley D, Kiconco L, Nabbanja P, Abeinomugisha D, Amusugut C, et al. Developing a coherent stratigraphic scheme of the Albertine Graben- East, Africa. J Earth Sci Eng. 2016;6:264-294. 
7. Kiconco L. The Semliki Basin, Uganda:Its sedimentation history and stratigraphy in relation to petroleum accumulation. Open UTC, 2005;p:206.

8. Abeinomugisha D. New concepts in the tectonic understanding of the Albertine Graben East African rift system. In Rift Link Presentation,2008;p:29.

9. Gradstein FM. Introduction. In The geologic time scale. 2012;1-29.

10. Germeraad JH, Hopping CA, Muller J. Palynology of tertiary sediments from tropical areas. Rev Palaeobotany Palynol. 1968;6:189-348.

11. Sah SCD . Palynology of an upper neogene profile from Rusizi Valley .Burundi; . Musée royal de l'Afriquecentrale. 1967.

12. Salard-Cheboldaeff M. Intertropical African palynostratigraphy from cretaceous to late quaternary times. J African Earth Sci. 1990;11:IN1-IN6.

13. Lukaye JM. Biostratigraphy and palynofacies of four exploration wells from the Albertine Graben, Uganda. American Assoc Petro Geo. 2009;p:50169.

14. Adeonipekun PA, Sowunmi MA, Richards K. A new late miocene to Pleistocene palynomorph zonation for the Western offshore Niger Delta. Palynology. 2017;41:2-16.
15. Stead DT, Awad MZ. Palynological zonation of cenozoic nonmarine sediments, Muglad Basin, Sudan. Rec Dev Applied Biostrat. 2005;pp:161-178.

16. Durugbo EU, Ogundipe OT, Ulu OK. Preliminary reports on middle miocene-early Pleistocene dinoflagellate cysts from the Western Niger Delta, Nigeria. Ozean J App Sci. 2011;4:373-394.

17. Gautier A. Fossil freshwater mollusca of the Lake Albert-Lake Edward Rift. Ann Mus R Afr Centr Tervuren Sci Géol. 1970;67:1-144.

18. Giwa GO, Oyede AC, Okosun EA. Advances in the application of biostratigraphy to petroleum exploration and production. Adapted from Presentation at the AAPG International Conference, Paris, France, 2006.

19. Roller S, Hornung J, Hunderer M, Ssemmanda I. Middle miocene to Pleistocene sedimentary record of rift evolution in the Southern Albert Rift .Uganda;. Int J Sci Eng Res. 2010;99:1643-1661.

20. RPS Energy. Palynological analysis of the turaco-3 and turaco-2 Wells, Block 3A, Albert Basin, Uganda. Confidential Report, Uganda, 2008.

21. Van Damme D, Pickford M. The late cenozoic thiaridae .mollusca, gastropoda, cerithioidea; of the Albertine Rift Valley .UgandaCongo; and their bearing on the origin and evolution of the Tanganyikanthalassoid malacofauna. Hydrobiologia. 2003;498:1-83. 